\title{
NEW CASES OF SUPERNUMERARY CHROMOSOMES IN CHARACIFORM FISHES
}

\author{
Paulo Cesar Venere ${ }^{1}$, Carlos Suetoshi Miyazawa ${ }^{2}$ and Pedro Manoel Galetti Junior ${ }^{3}$
}

\begin{abstract}
Supernumerary chromosomes were described for five species of Neotropical characiform fishes. These extra chromosomes were small, acrocentric and fully heterochromatic in Leporinus friderici from two different localities as well as in Leporinus sp., but metacentric and fully heterochromatic in Cyphocharax modesta and Prochilodus nigricans. In Characidium cf. zebra, this element was small, acrocentric and euchromatic. GC-rich DNA blocks were observed in the supernumerary chromosome of Leporinus sp. using chromomycin $\mathrm{A}_{3}$. The widespread occurrence of these extra chromosomal elements suggests their independent origins.
\end{abstract}

\section{INTRODUCTION}

Among vertebrates there are several descriptions of extra or supernumerary chromosomes, mainly in amphibians, reptiles and mammalians (Jones and Rees, 1982, for review). Their occurrence can be only related to sporadic events, and additional chromosomes might be an individual trait among the remaining individuals of a population. In fishes, an additional chromosome, for instance, was detected in only one individual of Parodon (Parodontidae) and in a specimen of Oligosarcus (Characidae), among several individuals (Falcão et al., 1984). In several cases, however, they are a common feature within the population or species, becoming generation to generation fixed in that population, and often called B chromosomes. In characiform fishes, true B chromosomes were first described in Prochilodus lineatus (= P. scrofa), in which up to five small heterochromatic chromosomes were observed cell to cell variable but present in most studied individuals (Pauls and Bertollo, 1983).

Other cases of extra chromosomes in fish are now well known (Venere and Galetti, 1985; Hochberg and Erdtmann, 1988; Oliveira et al., 1988; Foresti et al., 1989; Fenocchio and Bertollo, 1990; Oliveira and Foresti, 1993; Pastori et al., 1997). In Astyanax scabripinnis different populations have often shown one or two B chromosomes, or even up to five Bs, while several others showed none of these chromosomes (Salvador and Moreira-Filho, 1992; Maistro et al., 1992; Stange and Almeida-Toledo, 1993). Recently, a female-biased sex ratio phenomenon was described in association with the presence of $\mathrm{B}$ chromosome

\footnotetext{
${ }^{1}$ Departamento de Biologia, Instituto de Ciências e Letras do Médio Araguaia, Universidade Federal de Mato Grosso, 78698-000 Pontal do Araguaia, MT, Brasil.

${ }^{2}$ Departamento de Biologia e Zoologia, Instituto de Biociências, Universidade Federal de Mato Grosso, 78060-900 Coxipó, Cuiabá, MT, Brasil. Send correspondence to C.S.M. Rua Três, 106, Recanto dos Pássaros, 78075-230 Cuiabá, MT, Brasil.

${ }^{3}$ Departamento de Genética e Evolução, Universidade Federal de São Carlos, Caixa Postal 676, 13565-905 São Carlos, SP, Brasil.
}

in this species. Moreover, in some of the B-bearing populations of A. scabripinnis, the B chromosomes appear to be constrained to the highest altitude along the extent of the stream where these fishes inhabit (Vicente et al., 1996).

In the present, extra chromosomes are described in six species of Neotropical characiformes belonging to the families Anostomidae, Curimatidae, Prochilodontidae and Crenuchidae (Characidiinae) and an independent origin hypothesis is discussed.

\section{MATERIAL AND METHODS}

Five characiform species comprising four different families were cytogenetically studied.

Anostomidae: Sixteen specimens of Leporinus friderici collected in the Candeias River, near Porto Velho, $\mathrm{RO}$, and two individuals from the Araguaia River, near Barra do Garças, MT. Three specimens of Leporinus sp. (new species, 4-3 dentary formula), from Dois de Agosto Stream, a tributary of Rio das Mortes, near Araguaiana, MT, Amazon basin.

Prochilodontidae: Three individuals of Prochilodus nigricans from the Araguaia River, near Barra do Garças, MT, Amazon basin.

Curimatidae: Seventeen individuals of Cyphocharax modesta collected in the Mogi-Guaçu River, near Luis Antonio, SP, Upper Paraná basin.

Crenuchidae (Characidiinae): Twenty-eight specimens of Characidium cf. zebra from Passa-Cinco River, in the municipality of Ipeúna, SP, also in the Upper Paraná basin.

Mitotic chromosomes were prepared from anterior kidney cells as described by Bertollo et al. (1978). C-banding was done according to Sumner (1972), and chromomycin $\mathrm{A}_{3}\left(\mathrm{CMA}_{3}\right)$ staining was as described by Schmid (1980).

\section{RESULTS}

The karyotypes of all five species studied here were previously described (Galetti et al., 1981; Venere and 
Galetti, 1989; Pauls and Bertollo, 1990; Miyazawa and Galetti, 1994). In Anostomidae, the two Leporinus species studied had $2 n=54$ biarmed chromosomes in the normal karyotypes. However, among 16 specimens of $L$. friderici from Candeias River, one of them (unidentified sex) had an additional small acrocentric. Similarly, in the other locality sampled (Araguaia River), among two individuals of this species, one individual (unidentified sex) had an additional chromosome (small acrocentric). In Leporinus sp. from Dois de Agosto Stream one male among three individuals studied also showed one extra and small acrocentric (Figure 1a, b and c). Differently of L. friderici in which the extra chromosomes whenever detected were present in $100 \%$ of the analyzed cells, in Leporinus sp. it was observed in about $80 \%$ of the cells.

Among 17 specimens sampled of Cyphocharax modesta (Curimatidae), one male showed a small biarmed extra chromosome besides the chromosomes of the normal complement $(2 \mathrm{n}=54)$ (Figure $1 \mathrm{~d})$, and in prochilodontids, one male had two extra chromosomes in $85 \%$ of the analyzed cells, among three individuals of Prochilodus nigricans (Figure 1e). Finally, in Characidium cf. zebra, all of the specimens showed $2 \mathrm{n}=50$ biarmed chromosomes in the normal karyotype, except for one in which an additional small acrocentric was detected in about $25 \%$ of the cells (Figure 1f).

C-banding revealed that these supernumerary chromosomes were fully heterochromatic (Figure 2a, b, c and d), except in Characidium cf. zebra (Figure 2e). A small bright $\mathrm{CMA}_{3}$ band was detected in an interstitial position on the long arm of the extra chromosome of Leporinus sp. (Figure 3).

\section{DISCUSSION}

A main question about the extra chromosomes described here in different characiform fishes might be if they have or not a common origin. Undoubtedly, they came from different events, even though the mechanisms of origin of most of these extra chromosomes might be the same. Among Characiformes they appear to spring up several times, since they are morphologically and probably functionally diverse. Their frequencies also seem different among all species studied. In Leporinus, Cyphocharax and Characidium, for instance, the apparent rare occurrence of extra chromosomes might indicate recent events with incipient fixation in the populations. On the other hand, the morphologically similar small heterochromatic acrocentrics detected in three Leporinus species suggest an earlier and unique origin of this chromosome in this genus. In this case, their probably rare occurrence in the populations might indicate a selective disadvantage. In curimatids, previous studies in different populations of Cyphocharax modesta had also shown an extra chromosome, morphologically similar to that here reported (Venere and Galetti, 1985; Martins et al., 1996). This might sug- gest that this chromosome is ancient in this species, widely spread in the distribution area, despite to it occurs in a low frequency within those populations. In the genus Prochilodus two other species also share the presence of extra chromosomes. Up to five B chromosomes were previously reported in Prochilodus lineatus (Pauls and Bertollo, 1983). Small B chromosomes were also detected in P. cearensis (Pauls and Bertollo, 1990) and here in $P$. nigricans. The presence of these supernumerary chromosomes was not detected in other population of P. nigricans from the Amazon basin (Pauls and Bertollo, 1990). So, these chromosomes may represent a population characteristic in the Araguaia River or the frequency of this element in the Amazon population is very low. It seems that these small and extra chromosomes assemble a specific clade separated from the remaining species from the genus Prochilodus.

Different mechanisms have been proposed to explain the origin and maintenance of extra chromosomes in several organisms (Jones and Rees, 1982, for review). The heterochromatinization, however, appears to be a common process occurring during the differentiation of these chromosomes, since the extra chromosomes have often been shown fully heterochromatic. The extra chromosome here detected in Characidium cf. zebra, however, showed no heterochromatic segments, suggesting that the heterochromatin should have no role on the origin and development of this chromosome in this species. An absence of heterochromatin was also reported in supernumerary microchromosome of a curimatid fish, Steindachnerina insculpta (Oliveira and Foresti, 1993). Thus, it is strongly indicative that these extra chromosomes occurring in different characiform groups have arisen several times among these fishes, although in a minor taxon (Leporinus, for instance), they can be shared by several species.

The occurrence of a small bright $\mathrm{CMA}_{3}$ band in extra chromosome of Leporinus sp. is a very interesting feature. In fishes, as well as in amphibians, the chromomycin $\mathrm{A}_{3}$ has been useful to detect NOR independently of its activity (Schmid and Guttenbach, 1988). Since Ag staining was unable to detect any Ag-NORs in this extra chromosome, one might suppose that if the $\mathrm{CMA}^{+}$band is actually related to NOR sites, they should be inactive in this extra chromosome. Otherwise, these interstitial $\mathrm{CMA}^{+}$ band observed in the extra chromosome of Leporinus sp. might be related to a particular heterochromatin stainability, instead any presence of NOR sites.

Interestingly, most of the cases of extra chromosomes thus far reported in fishes is related to characiform species, even though other major groups such as Siluriformes may show some species with these chromosomes (Fenocchio and Bertollo, 1990; Dias and Foresti, 1993, among others). Moreover, it could be accounted for that all those fishes showing accessory chromosomes exclusively inhabit the Neotropical region. Similar report was made for various sex chromosome systems which are much 

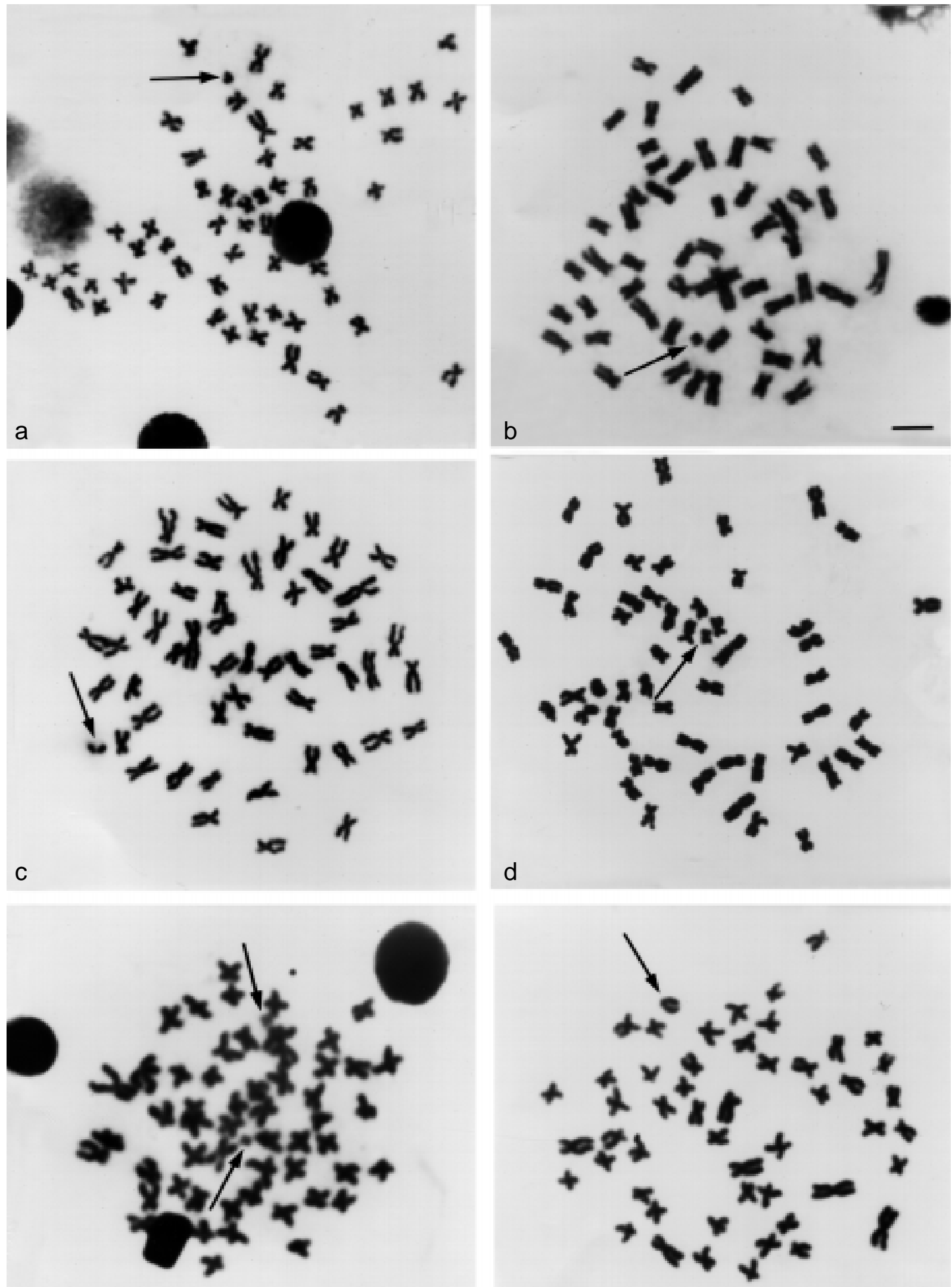

e

f

Figure 1 - Giemsa-stained metaphases of (a) Leporinus friderici from the Candeias River, (b) Leporinus friderici from the Araguaia River, (c) Leporinus sp., (d) Cyphocharax modesta, (e) Prochilodus nigricans and (f) Characidium cf. zebra. The arrows indicate the supernumerary chromosomes. Bar $=5 \mu \mathrm{m}$. 

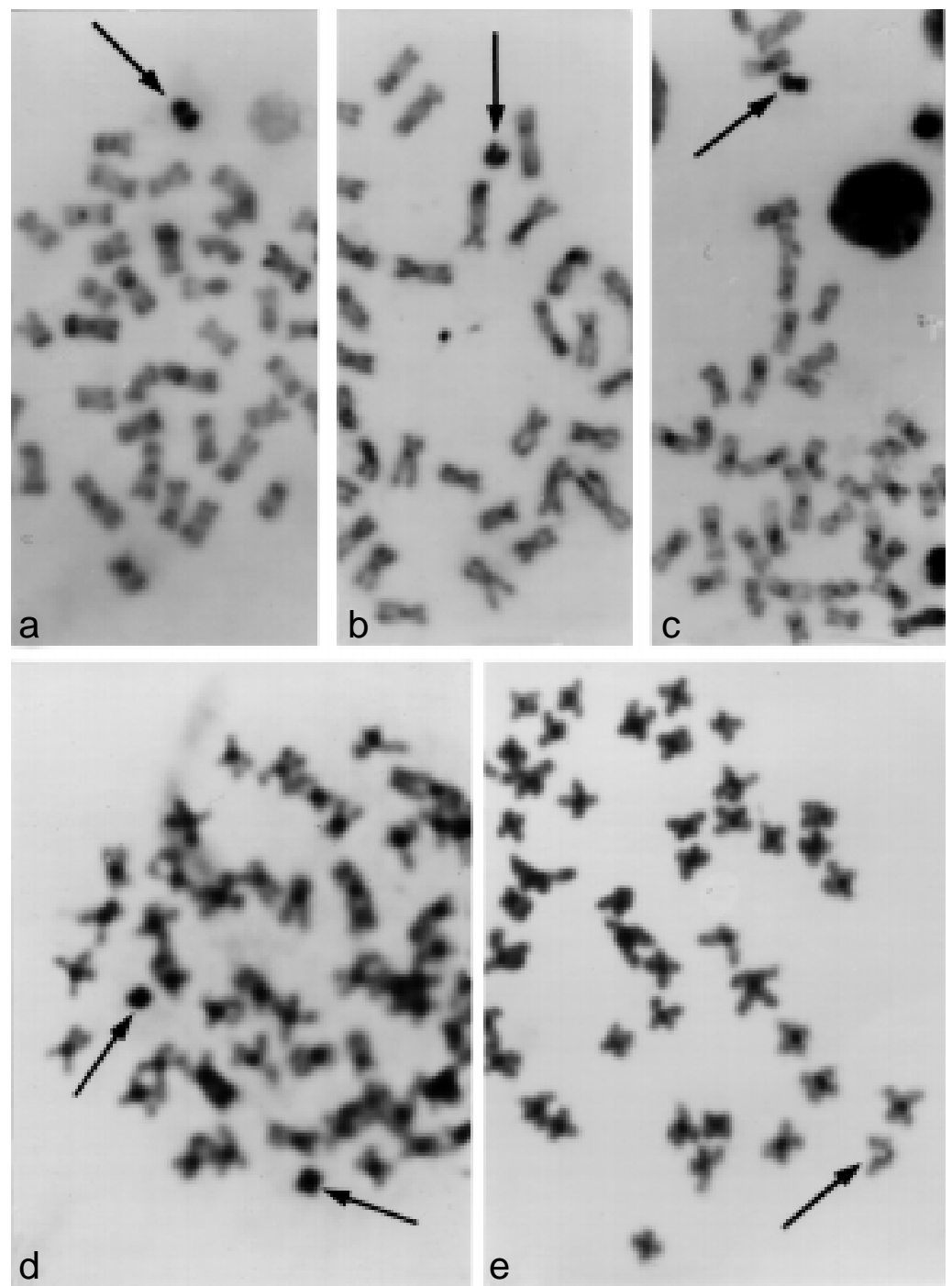

Figure 2 - C-banded partial metaphases of (a) Leporinus friderici from the Araguaia River, (b) Leporinus sp., (c) Cyphocharax modesta, (d) Prochilodus nigricans and (e) Characidium cf. zebra. The arrows indicate the supernumerary chromosomes.
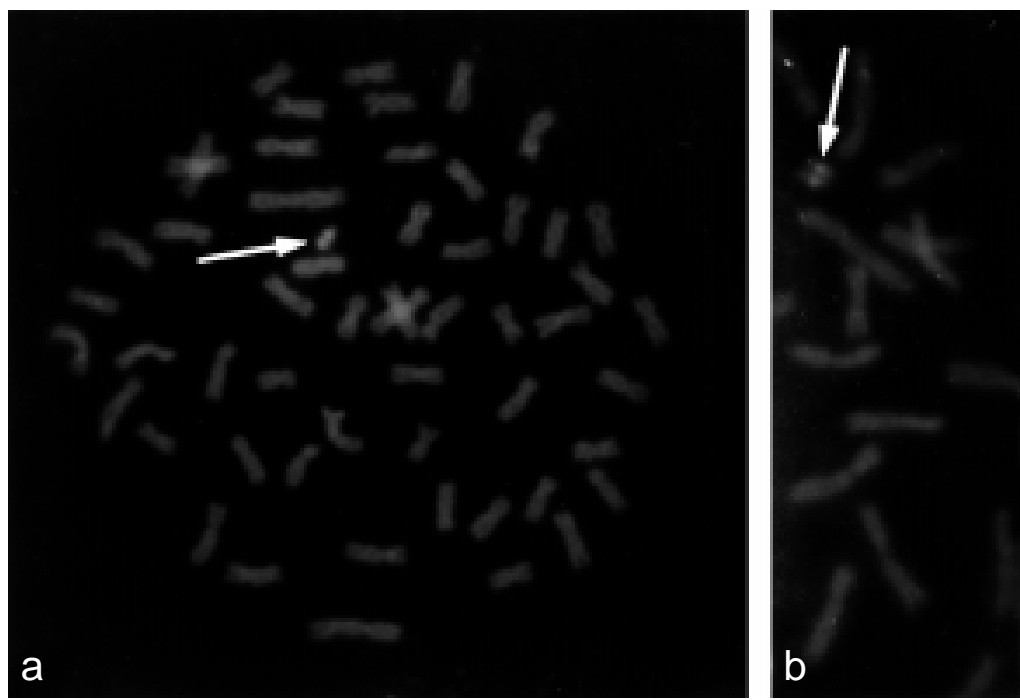

Figure 3 - Completely (a) and partially (b) $\mathrm{CMA}_{3}$-stained metaphases of Leporinus sp. The arrows indicate the supernumerary chromosome with a bright band on the long arm. 
more frequent in this geographic area (Moreira-Filho et $a l ., 1993)$, and independently of why it occurs, the chromosome diversity appears to be facilitated in this area. The findings of the present study and of the previous ones, therefore, are strongly indicative that the nature has found in Characiformes a pool of species on which different ways of origin and development of supernumerary chromosomes might have led to the general picture now observed.

\section{ACKNOWLEDGMENTS}

The authors thank Braulina Silva Morbeck of the ICLMA/UFMT and Ricieri Silvio Sichieri for help during the collection of Leporinus specimens. Research supported by CNPq, CAPES and FAPESP. Publication supported by FAPESP.

\section{RESUMO}

São descritos os cromossomos supranumerários observados em cinco espécies de peixes pertencentes a quatro famílias distintas de caraciformes neotropicais. Esses cromossomos mostraram-se pequenos, totalmente heterocromáticos e acrocêntricos em Leporinus friderici e Leporinus sp. e metacêntricos e totalmente heterocromáticos em Cyphocharax modesta e Prochilodus nigricans. Em Characidium cf. zebra um pequeno extra acrocêntrico é visto totalmente eucromático. Um pequeno segmento rico em pares de bases GC pôde ser observado no cromossomo extra de Leporinus sp. após a coloração com cromomicina $\mathrm{A}_{3}$. Alguns aspectos relacionados à origem desses cromossomos extras entre os caraciformes são discutidos.

\section{REFERENCES}

Bertollo, L.A.C., Takahashi, C.S. and Moreira-Filho, O. (1978). Cytotaxonomic considerations on Hoplias lacerdae (Pisces, Erythrinidae). Rev. Bras. Genét. I: 103-120.

Dias, A.L. and Foresti, F. (1993). Cytogenetics studies on fishes of the family Pimelodidae (Siluroidei). Rev. Bras. Genét. 16: 585-600.

Falcão, J.N., Moreira-Filho, O. and Bertollo, L.A.C. (1984). An additional chromosome in two fish species. Rev. Bras. Genét. VII: 109-118.

Fenocchio, A.S. and Bertollo, L.A.C. (1990). Supernumerary chromosomes in a Rhamdia hilarii population (Pisces, Pimelodidae). Genetica 81: 193-198.

Foresti, F., Almeida-Toledo, L.F. and Toledo Filho, S.A. (1989). Supernumerary chromosome system, C-banding pattern characterization and multiple nucleolus organizer regions in Moenkhausia sanctaefilomenae (Pisces, Characidae). Genetica 79: 107-114.

Galetti Jr., P.M., Foresti, F., Bertollo, L.A.C. and Moreira-Filho, O. (1981). Karyotypic similarity in three genera (Leporinus, Leporellus and Schizodon) of the family Anostomidae (Pisces, Teleostei). Rev. Bras. Genét. IV: 11-15.

Hochberg, V.B.M. and Erdtmann, B. (1988). Cytogenetical and morpho- logical considerations on Rhamdia quelen (Pisces, Pimelodidae). The occurrence of B chromosomes and polymorphic NOR regions. Rev. Bras. Genét. 11: 563-576.

Jones, R.N. and Rees, H. (1982). B Chromosome. Academic Press, London.

Maistro, E.L., Foresti, F., Oliveira, C. and Almeida-Toledo, L.F. (1992). Occurrence of macro B chromosome in Astyanax scabripinnis paranae (Pisces, Characiformes, Characidae). Genetica 87: 101-106.

Martins, C., Giuliano-Caetano, L. and Dias, A.L. (1996). Occurrence of a B chromosome in Cyphocharax modesta (Pisces, Curimatidae). Cytobios 85: 247-253.

Miyazawa, C.S. and Galetti Jr., P.M. (1994). First cytogenetical studies in Characidium species (Pisces, Characiformes, Characidiinae). Cytologia 59: 73-79.

Moreira-Filho, O., Bertollo, L.A.C. and Galetti Jr., P.M. (1993). Distribution of sex chromosome mechanisms in Neotropical fish and description of a ZZ/ZW system in Parodon hilarii (Parodontidae). Caryologia 46: 115-125.

Oliveira, C. and Foresti, F. (1993). Occurrence of supernumerary microchromosomes in Steindachnerina insculpta (Pisces, Characiformes, Curimatidae). Cytobios 76: 183-186.

Oliveira, C., Almeida-Toledo, L.F., Foresti, F. and Toledo, S.A. (1988). Supernumerary chromosomes, Robertsonian rearrangement and multiple NORs in Corydoras aeneus (Pisces, Siluriformes, Callichthyidae). Caryologia 41: 227-236.

Pastori, M.C., Fenocchio, A.S. and López, P.A. (1997). First description of microchromosome in the Anostomidae fish Schizodon nasutus from Argentina. Braz. J. Genet. 20: 425-427.

Pauls, E. and Bertollo, L.A.C. (1983). Evidence for a system of supernumerary chromosome in Prochilodus scrofa (Pisces, Prochilodontidae). Caryologia 36: 307-314.

Pauls, E. and Bertollo, L.A.C. (1990). Distribution of a supernumerary chromosome system and aspects of karyotypic evolution in the genus Prochilodus (Pisces, Prochilodontidae). Genetica 81: 117-123.

Salvador, L.B. and Moreira-Filho, O. (1992). B chromosome in Astyanax scabripinnis (Pisces, Characidae). Heredity 66: 50-56.

Schmid, M. (1980). Chromosome banding in Amphibia. IV. Differentiation of GC- and AT-rich chromosome regions in Anura. Chromosoma 7: 83-103.

Schmid, M. and Guttenbach, M. (1988). Evolutionary diversity of reverse (R) fluorescent chromosome bands in vertebrates. Chromosoma 97: 101-114.

Stange, E.R. and Almeida-Toledo, L.F. (1993). Supernumerary B chromosomes restricted to males in Astyanax scabripinnis (Pisces, Characidae). Rev. Bras. Genét. 16: 601-615.

Sumner, A.T. (1972). A single technique for demonstrating centromere heterochromatin. Expl. Cell Res. 75: 304-306.

Venere, P.C. and Galetti Jr., P.M. (1985). Natural triploidy and chromosome B in the fish Curimata modesta (Curimatidae, Characiformes). Rev. Bras. Genét. VIII: 681-687.

Venere, P.C. and Galetti Jr., P.M. (1989). Chromosome relationships of some Neotropical Characiformes of the family Curimatidae. Rev. Bras. Genét. 12: 17-25.

Vicente, V.E., Moreira-Filho, O. and Camacho, P.M. (1996). Sex-ratio distortion associated with the presence of B chromossome in Astyanax scabripinnis (Teleostei, Characidae). Cytogenet. Cell. Genet. 74: 70-75.

(Received September 3, 1998) 
